\title{
VIRTUAL EDUCATIONAL SPACE FOR YOUNG LEARNERS: ADVANTAGES AND CHALLENGES. COMPARATIVE RESEARCH
}

\author{
Eugenia Smyrnova-Trybulska ${ }^{1}$, Nataliia Morze ${ }^{2}$ and Iwona Mokwa-Tarnowska ${ }^{3}$ \\ ${ }^{1}$ University of Silesia in Katowice, Bankowa 12, 40-007 Katowice, Poland \\ Faculty of Ethnology and Sciences of Education. Bielska 62, 43-400 Cieszyn \\ ${ }^{2}$ Borys Grinchenko Kyiv University, Kyiv, Ukraine, 18/2, Bulvarno-Kudriavska St, Kyiv, Ukraine, 04053 \\ ${ }^{3}$ Gdansk University of Technology, Narutowicza 11/12, 80-233 Gdańsk, Poland
}

\begin{abstract}
The Internet has become a global medium without which it is difficult to imagine modern life. It provides enormous opportunities, but at the same time creates a lot of dangers especially for the youngest users. This article presents selected aspects of a preliminary analysis of "Children on the Web", research on the virtual educational space, the aim of which was to diagnose the conditions for safe use of the Internet in education, and its impact on the development of children, as well as threats and ways to prevent them. The respondents were in-service and pre-service teachers.
\end{abstract}

\section{KEYWORDS}

Virtual Education Space, Internet, Security, Network, Children, Teachers, Literary Media

\section{INTRODUCTION}

Researchers and scholars from different countries are increasingly asking the question at what age Internet education should begin and what group is responsible for that. Internet use is nearly ubiquitous among youth; risks associated with Internet use include cyberbullying, privacy violation and unwanted solicitation. Internet safety education may prevent these negative consequences (Moreno, Egan, Bare, Young, and Cox 2012).

Intense dynamic development of the global Internet has raised enormous possibilities - e-commerce, e-business, e-business, e-learning, and has posed dangers - cybercrime, cyberbullying and grooming, affecting children and young people in virtual space.

Adults are obliged to provide the young generation with security, both in traditional social space and in cyberspace. Nowadays, young people for whom digital media are an inseparable element of their everyday life are exposed to many dangers coming from cyberspace.

The issue of preventive and educational measures to be taken to ensure that the young generation is able to function safely in the real and virtual world is very important. An interdisciplinary context is necessary. (Marciniec, Marczuk, 2015). The research into this field should take into considerations the following determinants: the formal and legal context; educational context, psychological context; ethical context; context of security, protection and prevention.

\section{RESEARCH BACKGROUND}

Different researchers across the world have analyzed the interrelation between virtual space and behavior of children and youth. LaRose, Rifon, and Enbody (2008) present a framework to motivate safe online behavior that interprets prior research, and uses it to evaluate some of the current nonprofit online safety education efforts. 
The problem of children and young people's activity in virtual space and parental control in relation to this activity has been examined by Lithuanian scientists Geležinienė, Meliené, and Vaitkevičienè (2015). They address such questions as: what do children and adolescents most often do in virtual space, and what are the goals they have, and analyze whether there are major differences between boys' and girls' behavior in virtual space. They reveal how parents control children's and young people's activities on the Internet, how children perceive this control and what teachers think of it. The activities of students of Polish and foreign universities in an information environment, including the use of online resources and social networking sites in class and during extracurricular activities, are described by Smyrnova-Trybulska, Noskova, Yakovleva and Pavlova (2015). According to De Magalhães, Rose Silva, Magalhães and Anacleto (2011) the web is considered as a good resource to exchange knowledge, used by companies and schools to promote effective learning in e.g. agricultural area.

Research on kinds online has been carried out by the London School of Economics and Political Science (Kirwil, 2011). The project was financed by the EU Safer Internet Program and the Polish results. The study shows that two-thirds $(65.1 \%)$ of the Polish children who experienced active teacher support declare that they have mastered more than a half of the competencies enumerated in the survey. Those who have not experienced active teacher support, and yet have mastered half or more of their skills, amount to 45.6\% (Kirwil, 2011, p. 42).

In the population of Polish children aged 9 to 16, every fourth child has online contacts with strangers, almost every seventh has seen sex-related material on the Internet, every tenth has experienced negative emotions (anxiety or distress) while using the Internet, almost every twelfth has met in person an online acquaintance, and every seventeenth has been a victim of cyber aggression. In addition, almost every fourth child aged 11-16 has had access to online content that may have harmed the child's emerging value system, almost every seventh has received information with sexual undertones on the Internet (Kirwil, 2011, p. 44).

Although these Internet threats affect a smaller proportion of children (59\% of the children reported that they had not experienced any of the above online threats), their parents' underestimation of these threats is very common in Poland. The longer the child's uses the Internet, the more likely they are to encounter online threats. However, frequent use of the Internet also results in positive experiences, opportunities and benefits.

Polish children engage in more than the average number of online activities recorded for the whole of Europe, so their competency, also in activities specific to the safe use of the Internet, is relatively high. But a prolonged use of the Internet brings both more opportunities and more threats (Kirwil, 2011, p.44).

\section{SOCIAL PROGRAMS AND CAMPAIGNS}

The most important and well-known prevention programs include the government programs "Safer Together" (2006) and "Safe and Friendly School" (2014) (Marciniec and Marczuk, 2015, p. 35). They involve numerous activities that aim at strengthening security in schools and educational institutions.

The Foundation We Give Children the Strength (formerly the Nobody's Children Foundation) has since 1991 worked to ensure that all children have safe childhood and are treated with respect for their dignity and subjectivity. Its activities focus on protecting the youngest from harm and on minimizing the consequences of them experiencing violence.

The best-known projects (campaigns) include the:

- Helpline.org.pl aims is to help children and youth in situations of security threats on the Internet, and to bring about systemic changes that will effectively protect children and adolescents against technological threats

- Stop cyberbullying implemented since 2008 as part of the "Child on the Web" campaign

- Dyzurnet.pl, handled by experts from NASK, is a website for reporting illegal content on the Internet, it provides help in case of the violation of Internet user's rights.

It should be remembered that some websites, such as Flickr, Google locator, Foursquare, can be used not only for private or educational purposes, but they also pose a threat to users who upload to them their photos and other materials. Both teachers and children need to be aware that after publishing materials on the Internet, even if they are almost immediately removed, they will most likely remain on the Internet. Therefore, the key phrase for the child should be "Think before publishing!" (Bogdanova, 2012, p. 39). 
The security and blocking programs include Beniamin, Naomi, Ochraniacz, Visikid, WebControl, Norton Online Family, BelferCommander, Butterfly, Child's Guardian on the Internet, Student Guard, Visual Supervision. Most programs allow blocking unwanted websites, creating so-called Black List, setting a time limit for Internet use, creating the so-called White List - list of pages allowed, blocking communicators, EXE executables and MP3 files, which are often the carrier of inappropriate content, blocking the image finder, document downloads, mailing lists, access to electronic mail, SMS gates (Marciniec, Marczuk, 2015, p. 36).

International services and initiatives include the international website Safer Internet Day (SID) (https://www.saferinternetday.org/), the Ukrainian website The Center of the Best Internet (https://betterinternetcentre.org/); the project About the Internet (http://www.prointernet.in.ua/); the on-line course "Critical thinking for educators" (https://courses.prometheus.org.ua/courses/coursev1:CZ+CTFT101+2017_T3/about), available on the Prometheus platform. Over the years, Safer Internet Day (SID) has become a landmark event in the online safety calendar. Started as an initiative of the EU SafeBorders project in 2004 and taken up by the Insafe network as one of its earliest activities in 2005, it has grown beyond its traditional geographic zone and is now celebrated in approximately 140 countries worldwide.

Important determinants of raising the level of cyber security are media and IT education as well as the development of appropriate children's and youth's competencies regarding media education and media literacy, including responsible use of IT in the didactic process. In Poland these aspects have been addressed by Bednarek (2014), Gajda (2002), Juszczyk (2000), Morbitzer (2001, 2007), Siemienicki (2002), SmyrnovaTrybulska (2018), Tanaś (2005) and Wenta (2002). Their research targeted the determinants of the impact of media messages on the process of shaping attitudes and children's and young people's values. It indicated the need to protect the young generation against threats that may flow from virtual space. IT education (digital literacy) at various levels of education is discussed by Doyle (1992), Sysło (2000, 2003, 2017), Gurbiel, Hardt-Olejniczak, Kolczyk and Krupicka (2000), Kwiatkowska (2017), Morze (2014) and Smyrnova-Trybulska $(2014,2018)$. Their studies pay special attention to the development of young learners' computational thinking, programming skills and purposeful computer use for learning, development, entertainment.

\section{SELECTED RESEARCH RESULTS}

The study involved 106 post-graduate students as well as full-time and part-time pedagogy students at the Faculty of Ethnology and Educational Sciences in Cieszyn, University of Silesia in Katowice, Teachers from Gdańsk region, Poland and Borys Grinchenko Kyiv University, Kyiv, Ukraine and teachers from the Kiev region. The anonymous questionnaire contained 10 questions; it was developed using the Google Form tool and made available in electronic format. Answers to selected questions are presented below (Figures. 1-3).

In April 2018, the first preliminary results were obtained. Further research will be conducted on a larger scale and will target teachers from other provinces and countries.

The comparison of the survey results was made with the Mann-Whitney U test. The statistical analyses were performed with STATISTICA 13.01. In the case of question 1 all the answer options were assigned high values apart from " $c$ " (median $=4)$. The difference between them is not statistically significant $(p>0.05)$ except for "A1" and "A3", where $\mathrm{p}<0.05$.

Question 1: Please, assess the benefits of virtual space for the education of children on scale from 1 (lowest) to 5 (highest) or give your criteria (multiple choice question) (Figure 1). 


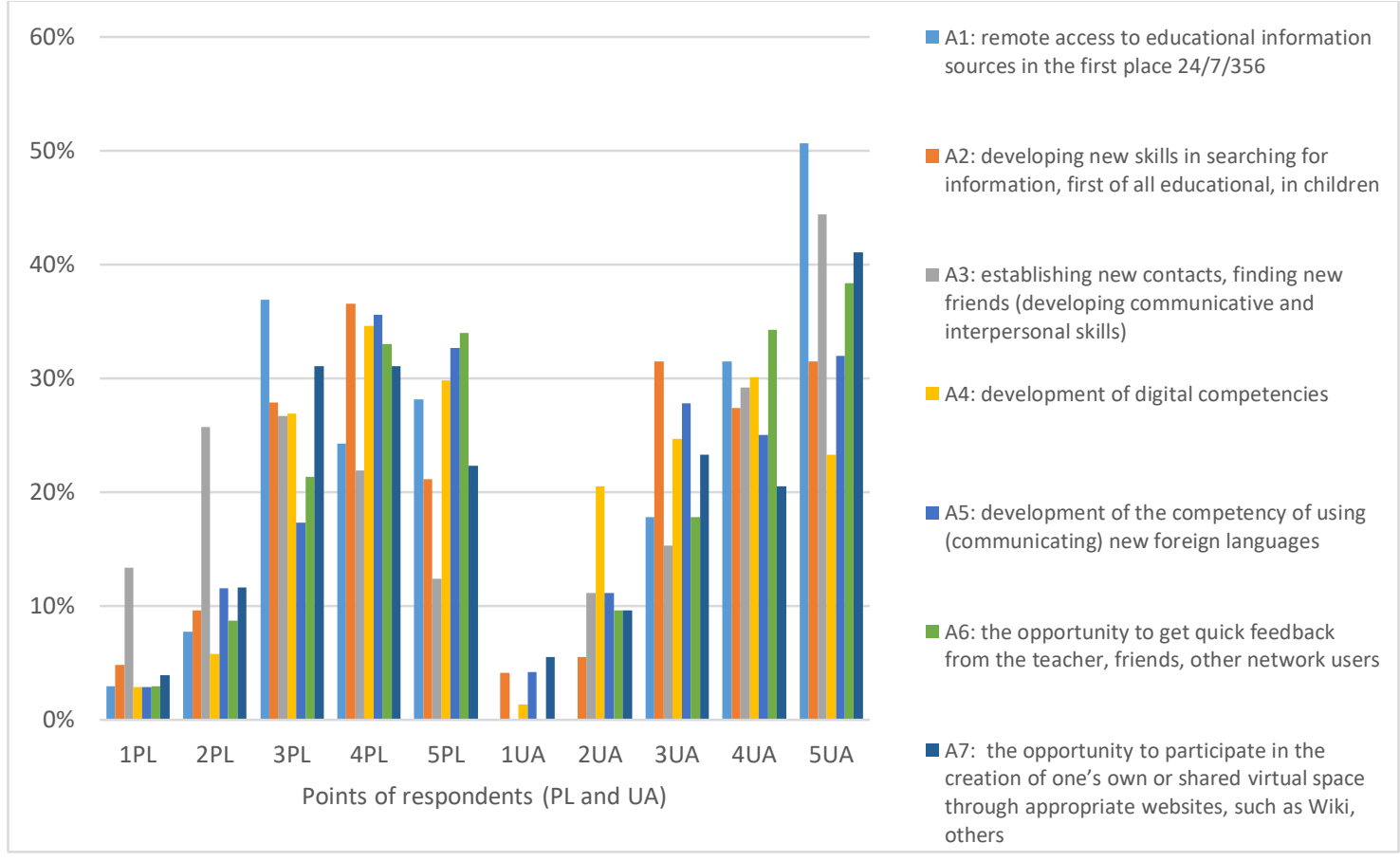

Figure 1. Distribution of Polish and Ukrainian respondents' answers to question 1 Source: Own study

Question 2: Please assess the risk of virtual space for education, upbringing, development of children on scale from 1 (lowest) to 5 (highest) (Figure 2).

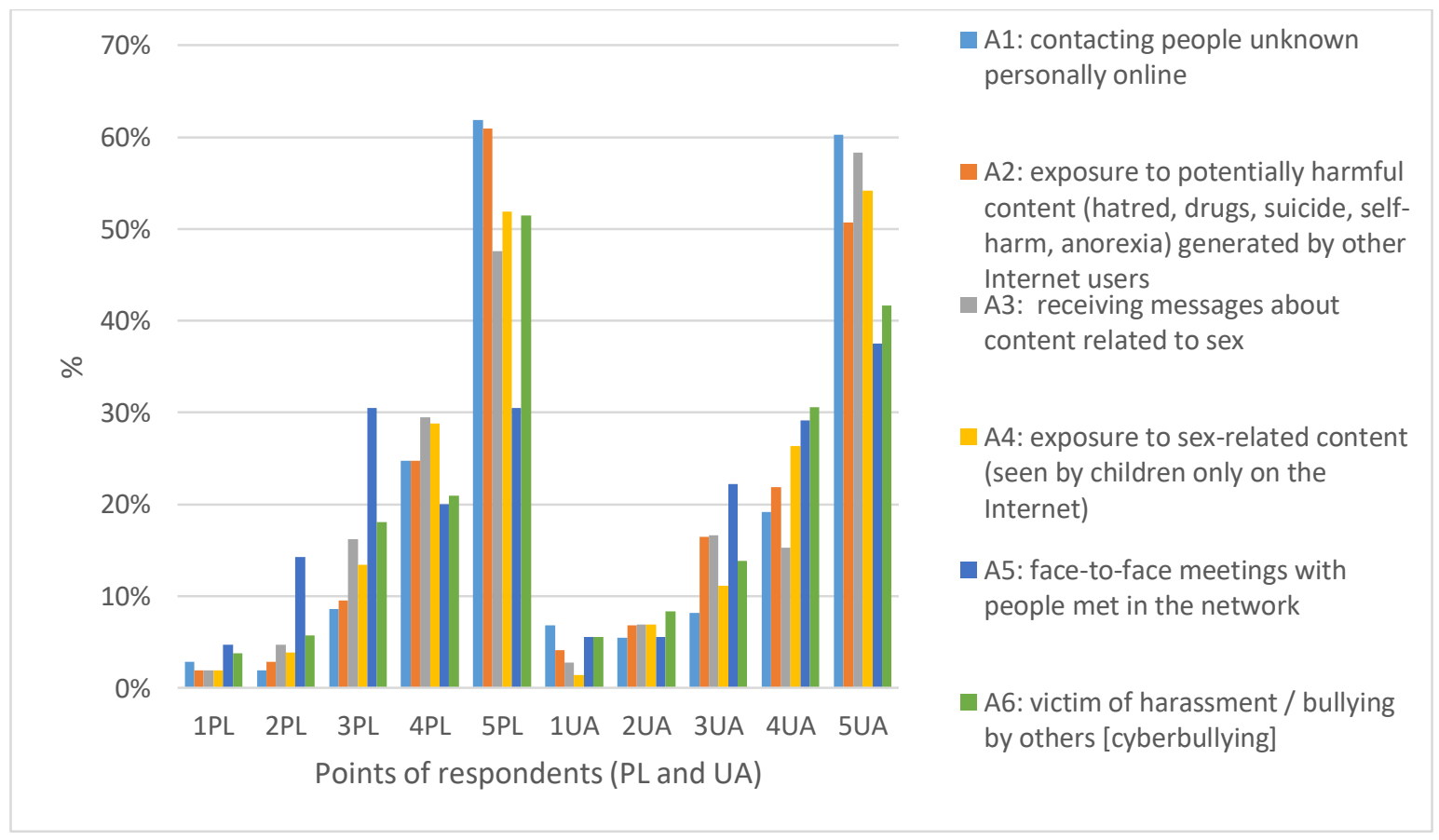

Figure 2. Distribution of Polish and Ukrainian respondents' answers to question 2 Source: Own study 
It can be seen that all the answer options were assigned high or very high values (median=5 or 4 ). It must be concluded that it is doubtful that meeting an online acquaintance in real life is relatively harmless, as such a person may turn out to be someone different from who they seemed to be.

Question 3 asked the respondents to provide min. 3 Polish websites that are useful for education, development, and upbringing of children (open question). The following Polish websites were mentioned: http://www.bajka.pl/, Sieciaki.pl, Matematyka w gry (http://matematykadladzieci.pl/), Poems for children (http://www.wierszedladzieci.pl/), ciufcia.pl (https://ciufcia.pl/), krainanauki.pl, kiddoland.pl, akademia-umysłu.edu.pl, http://teatrnn.pl/lexicon/design/wirtualne_miasteczko; https://zdobywcywiedzy.pl, legalnakultura.pl, edunews.pl, uczymy.pl, zadane.pl. The most frequently visited were wikipedia.pl and ściąga.pl, which means that teachers' competencies and support leave much to be desired and there is still much work to be done. The Ukrainian respondents mentioned: http://levko.info/, http://www.nosiki.cv.ua/, https://pustunchik.ua/ua, e-olymp.com, naurok.com.ua, https://znanija.com, https://interneturok.ru, https://prometheus.org.ua/, https://www.ed-era.com/, http://www.prointernet.in.ua/, https://lingva.ua/, Вчи.ua, levko.info, chytanka.com.ua, disted.edu.vn.uа, Острів знань, Parta.ua, Освіта.ua, others. The most often cited one was wikipedia.ua.

In Question 4 the respondents were asked to specify min. 3 foreign internet websites useful for education, development, upbringing of children (open question). Those mentioned included: prezi, kahoot, gloogster; Yummy.pl, Super Simple Song, EarlyStage.pl; https://supersimpleonline.com/; http://learnenglishkids.britishcouncil.org/en, http://www.english-4kids.com/; Quizlet, education world, NASA. But a vast majority indicated: Wikipedia, amazon.com, space.com, as well as MOODLE, Google, yahoo Skype and facebook. The respondents from Ukraine enumerated: http://youtube.com, http://www.fixiki.ru, http://en.childrenslibrary.org/, klavogonki.ru, code.org, "https://www.adme.ru/zhiznnauka/35-besplatnyh-obuchayuschih-sajtov-1088660/amp/, https://naurok.com.ua/post/internet-na-koristonlayn-resursi-dlya-vivchennya-fiziki?utm_source=push\&utm_medium=push\&utm_campaign=push, https://puzzle-english.com/, https://hourofcode.com/ua, https://uk.khanacademy.org/, Learningapps, kodu.org, duolingo, allforchildren.ru; Wikipedia, Instagram, Facebook and Youtube being mentioned by a vast majority.

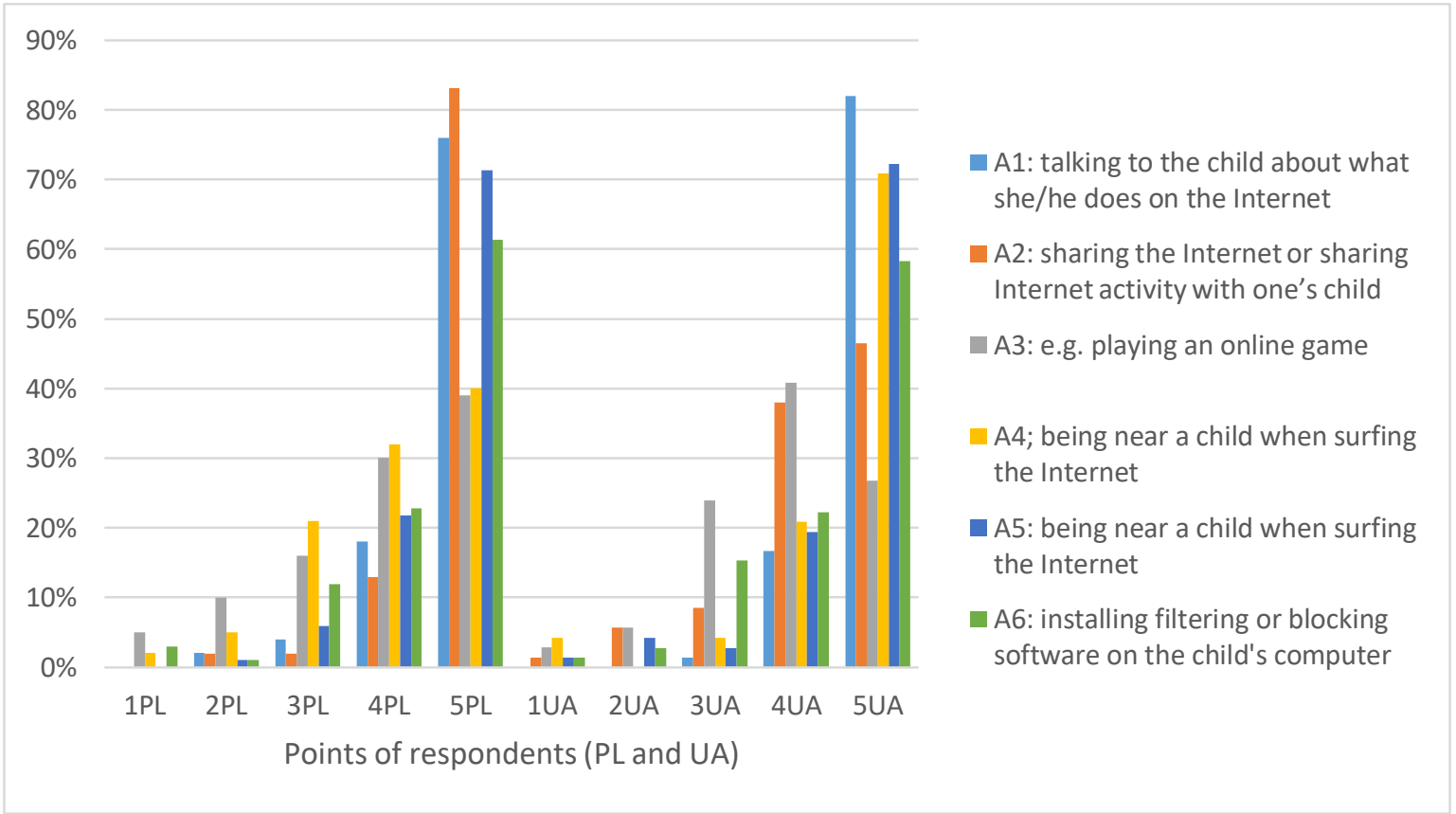

Figure 3. Distribution of Polish and Ukrainian Respondents' answers to question 5 Source: Own study 
In question 5 , the respondents were asked to rate on a scale from 1 (lowest) to 5 (highest) or give suggestions for measures that teachers and parents must take in (Figure 3).

All the answer options were assigned high or very high values (median $=5$ or 4 ). The difference between them is not statistically significant ( $\mathrm{p}>0.05$ ) except for "A2" and "A4", where $\mathrm{p}<0.05$, which is optimistic. Further research will aim to assess real skills, to design the didactic and educational process which entails, among other things, developing critical thinking, assertiveness, resilience to threats and making the right choice concerning Internet activity.

Question 6: "Evaluate the characteristics of an educational website on scale from 1 (lowest) to 5 (highest)." (Figure 4):

A1) Substantive criteria (purpose of website creation: definite, clear, quality (amount) of information: causal entity, update, correctness, credibility, amount of information, content: objectivity, originality, links, spelling, scope (content): thematic, chronological, formal, geographical, logical)

A2) Didactic criteria (user: support, usability, friendliness; reviews: page's rating; interactivity: e.g. Forum, Chat, Email, Blogs, Wiki)

A3) Technical criteria (links and navigation: correspondence, annotations, number of links, easy browsing; technical aspects: efficiency, equipment, search engines, application of standard solutions, organization of service, interactivity, speed of loading)

A4) Graphical criteria (structure and appearance of pages, organization of content: sections, subsections, clear page map, style of department headings and annotations; graphics and multimedia: audio, video, graphics; aesthetic impression: colors, fonts, format; professionalism and originality of graphics: authorization, copyright, artistic references, templates, original graphics)

A5) General (price: paid service, free service; originality of the website: original, average; friendly service: friendly, unfriendly; contact with the administrator: e.g. e-mail address, telephone)

A6) Other

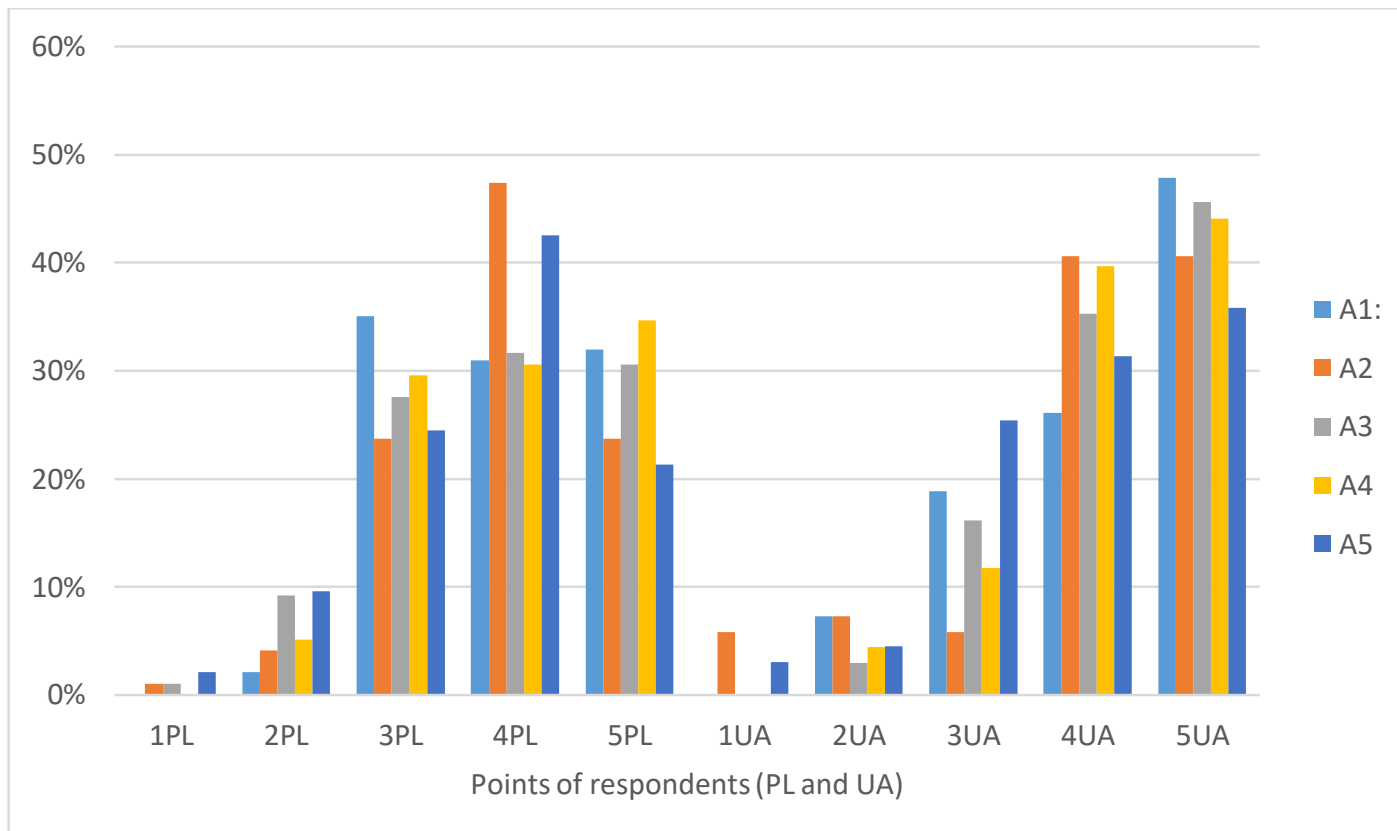

Figure 4. Distribution of Polish and Ukrainian respondents' answers to question 6 Source: Own study

The difference between the answers in the case of "A1", "A2" and "A5" is not statistically significant (p $>0.05$ ) except for "A3" and "A4", where $\mathrm{p}<0.05$.

Question 7: Rate the skills children should have to use a web browser and websites on scale from 1 (lowest) to 5 (highest) or suggest other skills (10-12 years old) (Figure 5): 
A1) adding a website to bookmarks (Favourites)

A2) finding information on how to use the Internet safely

A3) changing the privacy setting on one's profile on the social networking site

A4) blocking unwanted contacts

A5) comparing different websites to decide if the information provided is true

A6) deleting the history of visited pages

A7) blocking unwanted ads/spam/messages

A8) changing filter settings (which web pages can be viewed and which are not)

A9) reviewing social networks

A10) working with interactive services: Forum, Chat, Blog, other

A11) adding profiles to social networks

A12) adding profiles to interactive websites: Forum, Chat, Blog, other

A13) Other

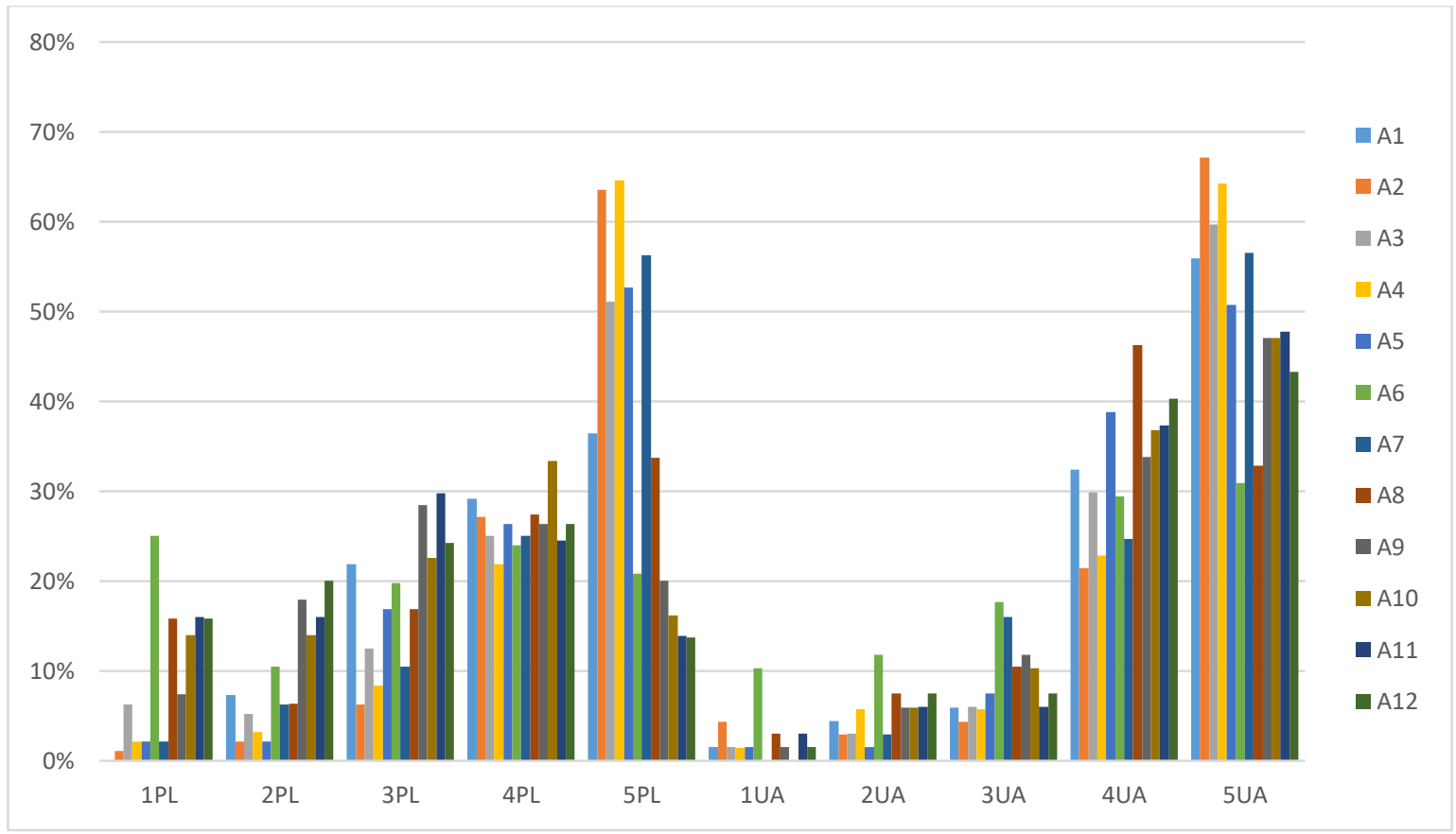

Figure 5. Distribution of Polish and Ukrainian respondents' answers to question 7 Source: Own study

The difference between the answers in the case of "A2", "A3", "A4", "A5", "A7", "A8" and "A13" is not statistically significant (p>0.05), whereas it is for "A1", "A6", "A9", “A10", "A11" and "A12” (p<0.05).

\section{FINAL REMARKS}

Because the creative and exploratory use of the Internet by children and young people and the use of its possibilities causes an inevitable risk of online threats, it is appropriate to provide a general recommendation. It is of utmost importance to protect children on the Internet and ensure their safety when surfing online, even the best software should be supplemented with protection and assistance, deliberately provided by parents. The child's skillful use of the Internet should be appreciated, and their awareness that "the Internet is more than just fun. This their life" must be raised.

Additionally, it is necessary to understand when to apply critical thinking and at what stages. The right conditions should be created for the development of critical thinking in students. 
In preventive and educational activities, a comprehensive and systemic approach should be applied to different groups of users - teachers, parents, and children.

Examples of good practice include the Polish website www.sieciaki.pl, the Innovative international MA programme "E-learning in cultural diversity", "ICT tools in childhood earlier education and primary school", a university curriculum module for $2^{\text {nd }}$ year BA students of pedagogy, teachers' specialization, which contains important expected topics related to security on the web.

\section{REFERENCES}

Bogdanova, D. A. (2012) On training and improving teachers' qualifications in the field of Internet security. Informatisation of education - 2012: pedagogical foundations for the development and use of electronic educational resources. ISBN: 978-985-518-732-6, pp. 36-39 [In Russian]

Doyle C., 1992: Outcome Measures for Information Literacy within the National Education Goals of 1990: Final Report of the National Forum on Information Literacy. Summary of Findings. Washington DC: US Department of Education.

Gajda J., Juszczyk S., Siemieniecki B., Wenta K., (2002). Media education. Toruń: Adam Marszałek Publishing House. [In Polish]

Geležinienė R., Melienė, R., Vaitkevičienè, A. (2015). Children and Adolescents in Virtual Space: Girls' and Boys' Behaviour and Attitude to Parental Control (May 2015). SOCIETY. INTEGRATION. EDUCATION. Proceedings of the International Scientific Conference, pp. 372-382

Gurbiel, E., Hardt-Olejniczak, G., Kolczyk, E., Krupicka H., Sysło, M.M. (2000) . Informatyka. Poradnik metodyczny dla nauczycieli gimnazjum. Warszawa: WSiP. [Methodical guide for junior high school teachers.] [In Polish]

Kirwil, L. (2011). Polish children on the Internet. Threats and security - part 2. Partial report from the EU Kids Online II survey conducted among children aged 9-16 and their parents. Warsaw: SWPS - EU Kids Online - PL. [In Polish]

LaRose, R., Rifon, Nora J. and Enbody, R. (2008). Promoting Personal Responsibility for Internet Safety COMMUNICATIONS OF THE ACM March 2008/Vol. 51, No. 3 pp.71-76 DOI: 10.1145/1325555.1325569

Marciniec B., Marczuk D.K. (2015) . Safety of children and young people in virtual space. Rozprawy Społeczne, 2 (IX), pp. 34-38. [In Polish]

Marczuk D., Kucała K. (2014). Freedom of speech in the virtual world - value abused W: J. Bednarek, A. Andrzejewska (ed.), Threats of cyberspace and the virtual world. Difin SA, Warsaw, pp. 140-159. [In Polish]

Morbitzer J., (2001) . Od motyki do komputera, czyli droga do spoleczeństwa informacyjnego. „Konspekt” nr 8, s. 41-46. [From hoe to computer, or the road to the information society. "Konspekt" No. 8, pp. 41-46.]

Moreno M. A, Egan, K.G., Bare, K., Young, H. N. and Cox E. D (2012) Internet safety education for youth: stakeholder perspectives. BMC Public Health201313:543 https://doi.org/10.1186/1471-2458-13-543

Morze, N., Smyrnova-Trybulska, E., (2014). Ways of formation and assessment of the formation of ICT competencies among future teachers Edukacja Humanistyczna, 1, 161-174. ISSN 1507-4943. [In Russian]

Noskova, T., Yakovleva, O., Pavlova, T., Smyrnova-Trybulska, E., (2015). Students in the Information Environment: a Study of Educational and Extracurricular Activities. International Journal Continuing Engineering Education and Life-long Learning, 25(4), ISSN 1560-4624. Pp.394-410.

Safer Internet Day international Internet Service On-line available at https://www.saferinternetday.org/

Smyrnova-Trybulska E. (2018) About Some Criteria for Estimation of the Quality of Educational Web-Site. New Information Technologies in Education and Science Vol. 1. Issue 12018 ISSN 2587-6910 c.118-121 [In Russian]

Smyrnova-Trybulska E. (2018). Information and communication technologies and e-learning in contemporary education. Monograph. Katowice: University of Silesia Press, 572 p. ISBN 978-83-226-3070-9 [In Polish]

Tanaś M. (ed.) (2005). Pedagogika @ środki informatyczne i media. Kraków: Wydawnictwo Impuls. [Pedagogy @ IT resources and media. Krakow: Impuls Publishing.] [In Polish]

The Center of the Best Internet. Ukrainian Internet services. On-line available at https://betterinternetcentre.org/

Vanessa Maia A. de Magalhães, Marcos A. Rose Silva, Walter C. P. Magalhães and Junia C. Anacleto (2011). Building Contextualized Web Hyperdocuments Taking into Consideration Readers' Culture and Literacy In Order To Allow Them To Understand These Hyperdocuments. IADIS International Conference $e$-Society Avila, Spain, March 10-13, 2011Proceedings, P.Kommers and P.Iasias (eds.) 2011 ISBN: 978-972-8939-46-5 pp.43-50

Vybor project web-site On-line available at http://vybor.zp.ua/?page_id=5043

Zakrzewski L. (2014). Education and modern technologies in the knowledge society, In: J. Bednarek (ed.), Man in the face of cyberspace opportunities and the virtual world. Difin SA, Warsaw, pp. 110-132. [In Polish] 